\title{
BENTONITE INTERCALATED ORGANOMETALLIC COMPLEX AS ADSORBENT OF PROCION RED
}

Lora Vitanesa ${ }^{1}$, Radja Nardo Purba ${ }^{1}$, Aldes Lesbani1 ${ }^{1}$, and Muhammad Said ${ }^{1}$

${ }^{1}$ Department of Chemistry Faculty Mathematic and Natural Science, Sriwijaya University

*Corresponding AuthorE-mail: loravitanesa@gmail.com

\begin{abstract}
Insertion of bentonite with organometallic compounds $\left[\mathrm{Cr}_{3} \mathrm{O}(\mathrm{OOCH})_{6}\left(\mathrm{H}_{2} \mathrm{O}\right)_{3}\left(\mathrm{NO}_{3}\right)\right]$ as adsorbent of procion red with comparison weight ratio of bentonite: organometallic compounds $\left[\mathrm{Cr}_{3} \mathrm{O}(\mathrm{OOCH})_{6}\left(\mathrm{H}_{2} \mathrm{O}\right)_{3}\left(\mathrm{NO}_{3}\right)\right]$ i.e.: $(2.5: 1),(1: 1)$, (1:2) and (1:3) has been done. The results of insertion bentonite were characterized using FT-IR spectrophotometer, XRD, and XRF. Furthermore, the product of optimum insertion was used as an adsorbent of procion red. The spectrogram from FT-IR shows the process of insertion was not optimum for every weight ratio. Characterization using XRD showed the optimum insertion process ratio (1:2) and (1:3) was indicated the presence of diffraction appearing at $2 \theta$ region by a shift in the diffraction angles 5.00 and $39 \circ$ from the original activated bentonite of $20.8^{\circ}$. Characterization using XRF analysis in the ratio (1:3) shows percentage of metal oxide $\mathrm{Cr}_{2} \mathrm{O}_{3}$ increase to $82.28 \%$, so at the ratio of 1:3, the process insertion of organometallic compounds into the bentonite has stated success base on its highest percentage. The adsorption process of insertion bentonite organometallic compounds $\left[\mathrm{Cr}_{3} \mathrm{O}(\mathrm{OOCH})_{6}\left(\mathrm{H}_{2} \mathrm{O}\right)_{3}\left(\mathrm{NO}_{3}\right)\right]$ ratio $(1: 3)$ shows the magnitude of the rate of adsorption $(\mathrm{k})$ at $0.004 \mathrm{~min}^{-1}$, the adsorption capacity (b), the largest at a temperature of $70{ }^{\circ} \mathrm{C}$ at $72.99 \mathrm{~mol} / \mathrm{g}$, the largest adsorption energy $(\Delta \mathrm{G})$ at a temperature of $60^{\circ} \mathrm{C}$ i.e. $17.05 \mathrm{~kJ} / \mathrm{mol}$, the largest enthalpy $(\Delta \mathrm{H})$ is 105720.8 $\mathrm{kJ} / \mathrm{mol}$, entropy $(\Delta \mathrm{S}) 315 \mathrm{~kJ} / \mathrm{mol}$ and $\mathrm{pH} 11$ has the biggest value of procion red adsorped, i.e. $33.38 \mathrm{mg} / \mathrm{L}$.
\end{abstract}

Keywords: Bentonite, Organometallic compound $\left[\mathrm{Cr}_{3} \mathrm{O}(\mathrm{OOCH})_{6}\left(\mathrm{H}_{2} \mathrm{O}\right)_{3}\left(\mathrm{NO}_{3}\right)\right]$.Adsorption, Procion Red

\section{INTRODUCTION}

Bentonite is one of the minerals whose abundance is quite large in nature, especially in Indonesia. Bentonite spread on the islands of Borneo, Sumatra, Sulawesi and Java. Bentonite is the most day consists of Montmorillonite with mineral such as quartz, calcite, dolomite, feldspars, and other minerals. Bentonite has the chemical formula $\left[(\mathrm{OH})_{4} \mathrm{Si}_{8} \mathrm{Al}_{4} \mathrm{O}_{20} \mathrm{nH}_{2} \mathrm{O}\right]$ which is silicate and alumina compounds contain chemically bound water (Sukandarrumidi, 1999). Bentonite is day minerals that have easy properties expand has cations in part layer that can be interchangeable so that the properties are very suitable to use as adsorbent and catalyst (Dewi and Hidayati, 2012).

The need for bentonite in the world industry tends to increase as adsorbent and catalyst but ability Bentonite adsorption is generally not high because Bentonite has a small spacing between layers and still, has impurity minerals (Noyan et al., 2007). Bentonite modifications can be carried out by means of chemical activation, physics activation as well as the insertion of the compound on the intercellular surface coated bentonite using an insertion compound. Bentonite modification is expected produce bentonite that has stability and distance between large layers. During this process inserted bentonite done with micro cations which is a compound the amine group (Altunlu and Yapar, 2007) and iron aluminum complex (Caglar et al., 2015).

\section{Article History}

Received: 9 October 2016

Accepted: 12 December 2016

DOI: 10.26554/sti.2017.2.1.9-16
Yolani (2012) conducted the research about the modified bentonite inserted metal aluminum uses poly diallyl dimethyl ammonium as the adsorbent of sodium dodecyl benzene sulphonate. Wang et al. (2009) also do inserted bentonite research with Aluminum using ammonium salt quarterner. The results shows metal bentonite inserted with Aluminum is shifting at an angle diffraction $8.4359^{\circ}$ with basal spacing value equal to 10.4817 is in region $2 \theta$ and Wang's research shows bentonite insertion of aluminum using salt quaternary ammonium undergoes shifts at $9.0941 \AA$ diffraction shrinkage with basal spading of $9.72449 \AA$ is in the area 20 . The product developed by Yolani (2012) and Wang (2009) have not been effective used as an adsorbent, because of the distance between the resulting layer is still small. This matter resulting from aluminum cations small size so cannot yet open the bentonite layer. To improve its effectiveness as an adsorbent, it required macro cations to produce a bentonite that has large interlayer spacing.

The large size of macro cation was developed by Lesbani (2008) which is a complex compound or organometallic synthesis results in the laboratory. Macro cation that used in synthesis ionic crystal macromolecules has the ability as adsorbents and also has ability as a catalyst (Uchida et al, 2012). Utami and Siburian (2016) was reported the organometallic trinudear complex as intercalant for bentonite. In this research, it will do the insertion on bentonite using compound complex organometallic $\left[\mathrm{Cr}_{3} \mathrm{O}(\mathrm{OOCH})_{6}\left(\mathrm{H}_{2} \mathrm{O}\right)_{3}\left(\mathrm{NO}_{3}\right)\right]$. The bentonite inserted using organometallic compounds $\left[\mathrm{Cr}_{3} \mathrm{O}(\mathrm{OOCH})_{6}\right.$ $\left(\mathrm{H}_{2} \mathrm{O}\right)_{3}\left(\mathrm{NO}_{3}\right)$ ], before and after will be characterized using a spectrophotometer FT-IR, XRD and XRF analysis, then applied as adsorbent of procionred. In addition, the factors such as kinetic parameters, parameters thermodynamics, the effect of 
$\mathrm{pH}$ of the solution, of influence the weight of adsorbent were also be determined.

\section{EXPERIMENTAL SECTION}

\section{Instrumentations}

The tools used in this research is a set of glass tools, filter paper, magnetic stirrer, bath (Hotplate), vacuum, oven, dropper drops, balance sheets analytical, UV-Vis spectrophotometer (Thermo Scientific Genesys 20), X-ray Diffraction (Shimadzu lab X-type 6000), Spectrophotometer FT-IR (Shimadzu-Pertige21), and X-ray Fluorescence (PAN Analytical Type Minipod)

\section{Material}

Ingredients used in this research is bentonite, aquadest, Chromium (III) nitrate nonahydrate compound $\left[\mathrm{Cr}\left(\mathrm{NO}_{3}\right)_{3}\right.$. $\left.9 \mathrm{H}_{2} \mathrm{O}\right]$, formic acid, sulfuric acid, Sodium hydroxide, hydrochloric acid, nitrogen gas, procion red dye.

\section{Procedures}

\section{Preparation of Bentonite and Characterization}

Bentonite is obtained from the district Sarolangun Jambi Province. Bentonite sample

which is obtained at a furnace at a temperature of $400^{\circ} \mathrm{C}$, and then added sulfuric adid and distilled water for 2 hours then dried. Bentonite is then smoothed in a way pulverized and filtered. Characterization of bentonite is done by using XRD, FT IR spectrophotometer, and analysis XRF.

\section{Synthesis of Organometallic Compounds $\left[\mathrm{Cr}_{3} \mathrm{O}(\mathrm{OOCH})_{6}\left(\mathrm{H}_{2} \mathrm{O}\right)_{3}\left(\mathrm{NO}_{3}\right)\right]$ and It's characterization (Lesbani et al.2008).}

Organometallic compounds $\left[\mathrm{Cr}_{3} \mathrm{O}(\mathrm{OOCH})_{6}\left(\mathrm{H}_{2} \mathrm{O}\right)_{3}\left(\mathrm{NO}_{3}\right)\right]$. is synthesized by: $\mathrm{Cr}\left(\mathrm{NO}_{3}\right)_{3} \cdot 9 \mathrm{H}_{2} \mathrm{O}$ as much as 40 grams is added $50 \mathrm{mLdistilled} \mathrm{water.} \mathrm{Stirred} \mathrm{by} \mathrm{using} \mathrm{magnetic} \mathrm{stirrer,} \mathrm{and} \mathrm{then}$ added $3 \mathrm{M} \mathrm{NaOH}$ of $10 \mathrm{~mL}$ for $10 \mathrm{~min}$ so that green solution is obtained. The green solution is filtered, the sediment taken and added formic acid as much as $12.5 \mathrm{~mL}$ and refluxed for 2 hours. The reflux solution is then filtered, and obtained by green crystals. Green crystal that has been dry analyzed using FT-IR spectrophotometer.

\section{Inorganic Compound Insertion $\left[\mathrm{Cr}_{3} \mathrm{O}(\mathrm{OOCH})_{6}\left(\mathrm{H}_{2} \mathrm{O}\right)_{3}\right.$ $\left(\mathrm{NO}_{3}\right)$ ] Into Bentonite and its characterization (Kouraichi et al.2015).}

Bentonite is made in the form of suspension by mixing as much as 2.5 grams Bentonite is activated with $200 \mathrm{~mL}$ of distilled water plus $100 \mathrm{~mL}$ of mixed $\mathrm{NaOH}$ with $1,2.5,5,7.5$ gr of organometallic compound while stirring using magnetic stirrer for 24 hours at room temperature while being fed by nitrogen gas. The results are obtained then filtered and dried. The solid of insertion result is characterized using XRD, FT-IR Spectrophotometer and XRF analysis.

\section{Determination ג Maximum Color Substance Procion Red}

Determination of maximum wavelength obtained by measuring the absorbance of the substance color procion red with Spectrofotometer UV-Vis at wavelength $400-600 \mathrm{~nm}$ so that will get the wavelength maximum.

\section{Absorption Process of Procion Red Using Adsorbent Bentonite Inserted Organometallic Compound $\left[\mathrm{Cr}_{3} \mathrm{O}\right.$ $\left.(\mathrm{OOCH})_{6}\left(\mathrm{H}_{2} \mathrm{O}\right)_{3}\left(\mathrm{NO}_{3}\right)\right]$. \\ Effect of adsorption time (Tien \& Ramarao, 2014).}

A total of 0.1 grams of bentonite adsorbent activated and inserted bentonite added into $50 \mathrm{~mL}$ of concentrated dye 100 ppm horizontally stirred using shaker at the time interval that has been determined. Variation of adsorption time varied ranging from 10, 20, 30, 40, 50, 60, 70, 80 and 90min. The dyestuff solution has passed through the adsorption process is separated, then measured concentration by using UV-VIS spectrophotometer.

\section{The influence of concentration and temperature (Mahmoud et al. 2016).}

A total of 0.1 grams of bentonite adsorbent activated and inserted bentonite mixed with $50 \mathrm{ml}$ of dye solution $(0.5,10,25$, $50,100 \mathrm{mg} / \mathrm{L})$ for insulated and bentonite $(0.5,10,25,40,60$ $\mathrm{mg} / \mathrm{L})$ for bentonite activated stirred by using shaker for 30 minutes at that temperature varied i.e. $30,40,50,60,70^{\circ} \mathrm{C}$. The mixture is filtered, and then the substance of the color that has been separated from the adsorbent is measured using UV-Vis spectrophotometry to know the concentration of residual color substances after color absorption process.

\section{Effect of $p H$}

Activated and inserted bentonite As much as $0.1 \mathrm{~g}$ added to $50 \mathrm{~mL}$ dye solution then stirred horizontally using a shaker at room temperature for 10 minutes. $\mathrm{pH}$ of dye solution is set at 3 , $4,5,6,7,8,9,10,11$, with the addition of $0.1 \mathrm{M} \mathrm{NaOH}$ and 0.1 $\mathrm{HCl} \mathrm{M}$. The color solution is then separated and residual concentration after the adsorption process was measured using a UV-Vis spectrophotometer.

\section{Spectroscopic and Diffraction Studies}

As much as 0.1 gram of adsorbent is mixed $50 \mathrm{~mL}$ of dye with concentration $100 \mathrm{mg} / \mathrm{L}$ and $60 \mathrm{mg} / \mathrm{L}$. The mixture is stirred using horizontal shaker for 1 hour. The mixture is separated by process filtering and then adsorbed dried adsorbents were analyzed using FT-IR spectrophotometer to know changes before and after the process adsorption.

\section{Data Analysis}

The success of the bentonite insertion process with organometallic compounds $\left[\mathrm{Cr}_{3} \mathrm{O}(\mathrm{OOCH})_{6}\left(\mathrm{H}_{2} \mathrm{O}\right)_{3}\left(\mathrm{NO}_{3}\right)\right]$ is observed from the data XRD, FT-IR Spectrophotometer, and analysis XRF. It is expected the insertion process only require one layer using a compound organometallic $\left[\mathrm{Cr}_{3} \mathrm{O}(\mathrm{OOCH})_{6}\left(\mathrm{H}_{2} \mathrm{O}\right)_{3}\left(\mathrm{NO}_{3}\right)\right]$ to form a workable bentonite by observed the effect of kinetic and thermodynamic parameters, aand the effect of $\mathrm{pH}$ of the bentonite kinetics solution Insertion of organometallic compounds $\left[\mathrm{Cr}_{3} \mathrm{O}(\mathrm{OOCH})_{6}\left(\mathrm{H}_{2} \mathrm{O}\right)_{3}\left(\mathrm{NO}_{3}\right)\right]$ for ddetermine the absorption rate with assume that the adsorption process oocurs following the model of the adsorption equation Langmuir as follows:

$$
\ln \frac{\left(C_{0} / C\right)}{C}=k_{1} \frac{t}{C}+K
$$


where :

Co: initial concentration of procion red, C: Procion red concentration after time $t, \mathrm{C}$ : residual concentration, $\mathrm{K}_{1}$ : slope

$\mathrm{T}$ : the adsorption time that follows Langmuir's adsorption equation model, $\mathrm{K}$ : intercept

Parameter thermodynamics of adsorption process Bentonite insertion $\left[\mathrm{Cr}_{3} \mathrm{O}(\mathrm{OOCH})_{6}\left(\mathrm{H}_{2} \mathrm{O}\right)_{3}\left(\mathrm{NO}_{3}\right)\right]$ i.e. $\Delta \mathrm{H}, \Delta \mathrm{S}, \Delta \mathrm{G}$ are determined by the following equation:

$\mathrm{E}_{\mathrm{ads}}=-\Delta \mathrm{G}_{\mathrm{ads}}=\mathrm{RT} \ln \mathrm{K}$

Where :

$\mathrm{K}_{\mathrm{d}}$ : coefficient of adsorbate distribution (qe/Ce), $\Delta \mathrm{H}$ : enthalpy, $\Delta \mathrm{S}$ : entropy, R: general gas constant $(8.314 \mathrm{~J} / \mathrm{mol} \mathrm{K})$ and $\mathrm{Q}$ : temperature

The bonds formed between the adsorbate and the adsorbent is studied through spectroscopy and diffraction compared with adsorbent before the interaction of inserted bentonite Organometallic compounds $[\mathrm{Cr} 3 \mathrm{O}(\mathrm{OOCH}) 6(\mathrm{H} 2 \mathrm{O}) 3(\mathrm{NO} 3)]$. Absorption capacity is based on formula:

$$
\mathrm{c} / \mathrm{m}=1 / \mathrm{bK}+\mathrm{c} / \mathrm{b}
$$

Where :

C: the concentration of metal ions in the solution at equilibrium, $\mathrm{K}$ : contants of eqilibrium, $\mathrm{m}$ : adsorbent mass, b: adsorption capacity

\section{RESULTS AND DISCUSSION}

Result of synthesis and characterization of compounds Organometallic $[\mathrm{Cr} 3 \mathrm{O}(\mathrm{OOCH}) 6(\mathrm{H} 2 \mathrm{O}) 3(\mathrm{NO} 3)]$ using Spectrophotome ter FTIR

Organometallic compounds $\left[\mathrm{Cr}_{3} \mathrm{O}(\mathrm{OOCH})_{6}\left(\mathrm{H}_{2} \mathrm{O}\right)_{3}\left(\mathrm{NO}_{3}\right)\right]$ was synthesized under atmospheric conditions without any special protection against Ligands (L) as well as organic groups (R) so that easy to do. During the synthesis process, formic acid was added and reflux process is done for 2 hours to obtain a green crystal solid which is an organometallic compound $\left[\mathrm{Cr}_{3} \mathrm{O}(\mathrm{OOCH})_{6}\left(\mathrm{H}_{2} \mathrm{O}\right)_{3}\left(\mathrm{NO}_{3}\right)\right]$. The Organometallic compounds was characterized using FT-IR spectroscopy to know the presence of $\mu-3$ chromium-oxygen group as the typical of symmetrical organometallic compounds (Ohto et al., 1995). The FT-IR spectra of Organometallic compounds $\left[\mathrm{Cr}_{3} \mathrm{O}(\mathrm{OOCH})_{6}\right.$ $\left.\left(\mathrm{H}_{2} \mathrm{O}\right)_{3}\left(\mathrm{NO}_{3}\right)\right]$. is presented in Figure 1.

Figure 1 shows the specific vibrations $\mu-3$ that known as $\mathrm{Cr}_{3}-\mathrm{O}$ in Organometallic $\left[\mathrm{Cr}_{3} \mathrm{O}(\mathrm{OOCH})_{6}\left(\mathrm{H}_{2} \mathrm{O}\right)_{3}\left(\mathrm{NO}_{3}\right)\right]$. Appears on wave number $648 \mathrm{~cm}^{-1}$ with sharp intensity. The presence of formic adid groups which are $\mathrm{C}-\mathrm{H}$ vibrations and $\mathrm{O}-\mathrm{H}$ vibrations is identified at wave number 2924-3425 $\mathrm{cm}^{-1}$ which are specific characteristic of the aliphatic compound. Nitrate compounds which are ions

The opponent is identified on the wave number $1381 \mathrm{~cm}^{-1}$ (Handayani et al, 2013). The Organometallic compound $\left[\mathrm{Cr} 33(\mathrm{OOCH})_{6}\left(\mathrm{H}_{2} \mathrm{O}\right)_{3}\left(\mathrm{NO}_{3}\right)\right]$. furthermore used as insertion on activated natural bentonite and its products will be applied as dye adsorbent of procion red.

\section{Identification of natural bentonite and activated bentonite using FT-IR Spectrophotometer, XRD, and XRF analysis \\ Natural bentonite is activated using two ways, the first is} physical i.e. Bentonite furnace at a temperature of $400^{\circ}$ with the aim of expanding the surfacevof Bentonite granules. The second process is chemically using sulphuric acid aims to convert existing $\mathrm{Ca}^{+}$cations into Ca-bentonite to $\mathrm{H}^{+}$and released the ions of $\mathrm{Al}, \mathrm{Fe}$, and $\mathrm{Mg}$ ions and impurities on the lattice structure so that the natural bentonite becomes active (Simamora et al., 2016). The result of natural bentonite the activated is then characterized using FTIR Spectrophotometer, XRD, and XRF analysis as presented in Figure 2, Figure 3 and Table 1.

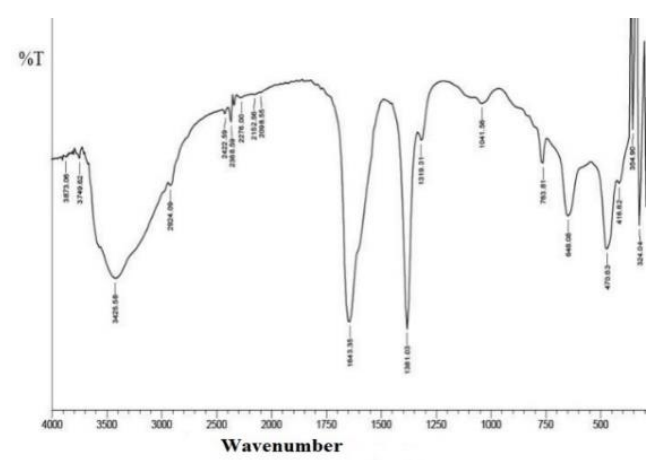

Figure 1. FT-IR spectra of the compound Organometallic [Cr3O $(\mathrm{OOCH}) 6(\mathrm{H} 2 \mathrm{O}) 3](\mathrm{NO} 3)]$

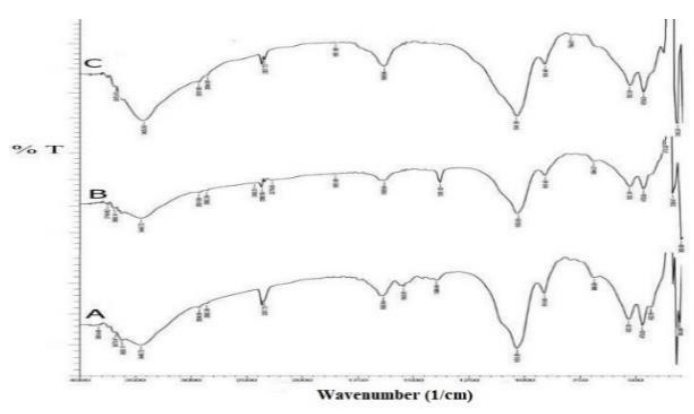

Figure 2. FTIR spectrum: (A) natural bentonite, (B) bentonite heating $400^{\circ} \mathrm{C},(\mathrm{C})$ bentonite after adidification

Figure 2 can be divided into two regions: the main is in the range of wave numbers $300-1000 \mathrm{~cm}^{-1}$ denotes the area of identification inorganic compounds and span areas wave number 1000-4000 $\mathrm{cm}^{-1}$ shows the basis of organic uptake. Identification of natural bentonite is determined by a hydroxy group caused by a molecule absorbed $\mathrm{O}-\mathrm{H}$ at the surface of the octahedral layer and $\mathrm{Si}-\mathrm{O}-\mathrm{Si}$ coating groups Tetrahedral (Koestiari, 2014). The wave data of natural bentonite, bentonite after heating with a temperature of $400{ }^{\circ} \mathrm{C}$ and bentonite after acidification can be seen on Table 1 .

Natural bentonite (D) indicates the presence of bentonite at the 5-6 diffraction peaks. Mineral of Montmorillonite was seen at the peak of 18 and silicate minerals at the peak of 20. On bentonite heating $400{ }^{\circ} \mathrm{C}(\mathrm{E})$, bentonite is reduced because of the warming but silicate minerals and fixed montmorillonite 
minerals. At the acidification bentone, a shifting mineral of montmorillonite residing on the peak of 25-26 and appear mineral illite on the peak of 19 . Based on figure 7 is known that the largest diffraction appears at the corner region diffraction $19.4^{\circ}, 34.6^{\circ}$, and $20.8^{\circ}$ located in the $2 \theta$ region indicating the presence mineral montmorillonite, silicate minerals, and mineral illite. The typical diffraction of all Bentonite type indicates that bentonite has a high crystallinity.

The results of XRD diffraction analysis shows the oxides present decreased the amount caused by thermal activation process and acid activation so the impurities are decreasing. This diffraction result is supported by data analysis quantitative of $\mathrm{XRF}$ that the natural bentonite is composed from mineral montmorillonite containing silica and alumina with the largest compositions that produce percentage of amount of $\mathrm{Al}_{2} \mathrm{O}_{3}$ and $\mathrm{SiO}_{2}$ metal oxides by $17 \%$ and $43.6 \%$. The other metal oxides are measured i.e. $\mathrm{P}_{2} \mathrm{O}_{5}$ of $0.71 \%, \mathrm{~K}_{2} \mathrm{O}$ of $0.2 \%, \mathrm{CaO}$ of $0.99 \%$, $\mathrm{TiO}_{2}$ of $1.87 \%, \mathrm{~V}_{2} \mathrm{O}_{5}$ of $0.11 \%, \mathrm{Cr}_{2} \mathrm{O}_{3}$ of $0.075 \%, \mathrm{MnO}$ of $0.15 \%, \mathrm{Fe}_{2} \mathrm{O}_{3}$ of $33.39 \%$, $\mathrm{NiO}$ of $0.87 \%, \mathrm{CuO}$ of $0.15 \%, \mathrm{ZnO}$ of $0.09 \%, \mathrm{Re}_{2} \mathrm{O}_{7}$ of 0.11 , and $\mathrm{Eu}_{2} \mathrm{O}_{3}$ of $0.2 \%$.

Table 1. Data of bentonite wave numbers of natural bentonite, heating bentonite and adidification bentonite

\begin{tabular}{lll}
\hline Compound & $\begin{array}{l}\text { Wave } \\
\text { number }\end{array}$ & Group \\
\hline Natural bentonite & 470.6 & $\mathrm{v}(\mathrm{Si}-\mathrm{O}-\mathrm{Si})$ \\
& 532.3 & $\mathrm{v}(\mathrm{Al}-\mathrm{O}-\mathrm{Si})$ \\
& 686.6 & $\mathrm{v}(\mathrm{si}-\mathrm{O})$ \\
& 1635.6 & $\mathrm{v}(\mathrm{O}-\mathrm{H})$ \\
& 3448.7 & $\mathrm{~V}(\mathrm{H}-\mathrm{O}-\mathrm{H})$ \\
Heating & 3626.1 & $\mathrm{~V}(\mathrm{o}-\mathrm{H})$ \\
bentonite & 470.6 & $\mathrm{v}(\mathrm{v}(\mathrm{Si}-\mathrm{O}-\mathrm{Si})$ \\
& 532.3 & $\mathrm{v}(\mathrm{Al}-\mathrm{O}-\mathrm{Si})$ \\
& 694.3 & $\mathrm{v}(\mathrm{Si}-\mathrm{O})$ \\
& 1635.6 & $\mathrm{v}(\mathrm{O}-\mathrm{H})$ \\
Acidification & 3448.7 & $\mathrm{v}(\mathrm{H}-\mathrm{O}-\mathrm{H})$ \\
bentonite & 3695.6 & $\mathrm{v}(\mathrm{O}-\mathrm{H})$ \\
& 470.6 & $\mathrm{v}(\mathrm{v}(\mathrm{Si}-\mathrm{O}-\mathrm{Si})$ \\
& 532.3 & $\mathrm{v}(\mathrm{Al}-\mathrm{O}-\mathrm{Si})$ \\
& 694.3 & $\mathrm{v}(\mathrm{Si}-\mathrm{O})$ \\
& 1635.6 & $\mathrm{v}(\mathrm{O}-\mathrm{H})$ \\
& 3448.7 & $\mathrm{v}(\mathrm{H}-\mathrm{O}-\mathrm{H})$ \\
& 3600.2 & $\mathrm{v}(\mathrm{O}-\mathrm{H})$ \\
\hline
\end{tabular}

Further characterization of natural bentonite and activated natural bentonite carried out using an XRD analyst is presented in Figure 3.

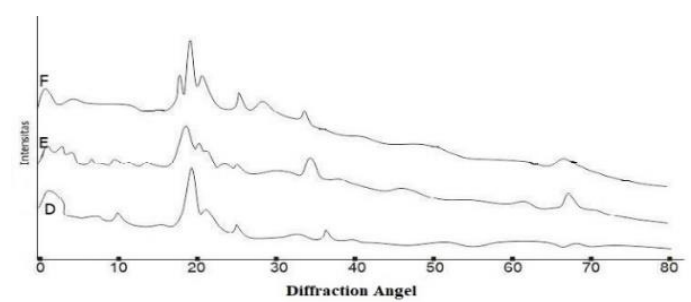

Figure 3. XRD diffraction patterns for: (D) natural bentonite, (E) Bentonite heating $400^{\circ} \mathrm{C}$ and $(\mathrm{F})$ acid-activated bentonite
Activation on natural bentonite caused a decrease in the percentage value minor metal oxide. This corresponds to a function of physical activation that can degrade percentage of impurity on natural bentonite and eliminating some minor metal oxides. On the activation of natural bentonite using sulphuric acid $\left(\mathrm{H}_{2} \mathrm{SO}_{4}\right)$ also causes a decrease someminor metal oxides are caused by the metal oxides contained in bentonite is bound to the $\mathrm{H}^{+}$ion and causes layers between bentonite layers open.

Table 2. The data of percentage of metallic oxide using XRF

\section{The identification results of Insertion of natural activated Bentonite using Spectrophotometer FTIR, XRD and XRF}

Natural bentonite is then activated inserted using organometallic compounds $\left[\mathrm{Cr}_{3} \mathrm{O}(\mathrm{OOCH})_{6}\left(\mathrm{H}_{2} \mathrm{O}\right)_{3}\left(\mathrm{NO}_{3}\right)\right]$ with addition of aquadest $(\mathrm{H} 2 \mathrm{O})$ and sodium hydroxide to form a suspension. Natural bentonite is inserted with 4 comparisons bentonite: organometallic compounds (2.5: 1), (1: 1), (1: 2) and (1: 3) with a view to determine the optimal insertion bentonite. To identify the natural bentonite of the insertion, it has been done the characterization using FT-IR spectrophotometer, XRD analysis, and XRF analysis. FT-IR spectra obtained can be seen in Figure 4, diffractogram XRD is presented in Figure 5, and the results of the analysis XRF in Table 2.

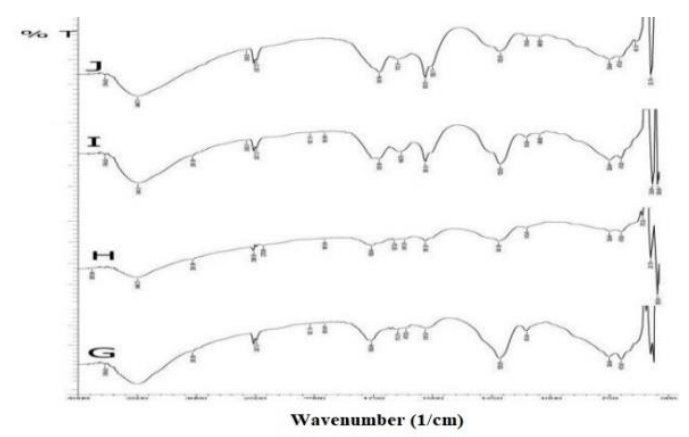

Figure 4. FTIR spectrum of insertion bentonite with a ratio of 2.5: $1(\mathrm{G}) ; 1: 1(\mathrm{H}) ; 1: 2(\mathrm{I}) ; 1: 3(\mathrm{~J})$

Figure 4 presents the functional group observed i.e. dusters of the compound organometallic $\left[\mathrm{Cr}_{3} \mathrm{O}(\mathrm{OOCH})_{6}\left(\mathrm{H}_{2} \mathrm{O}\right)_{3}\right.$ $\left.\left(\mathrm{NO}_{3}\right)\right]$. and bentonite groups are in the range of the wave number of 300-4000 $\mathrm{cm}^{-1}$. On comparison (2.5:1) indicates the presence $\mathrm{Cr}-\mathrm{O}$ vibration at the wave number of $670 \mathrm{~cm}^{-1}$ and also the formic acid ligands were shown by the vibrations, C-H, C-O, and O-H appear on the wave number of 2931,8-3448,7 $\mathrm{cm}^{-1}$. On comparison (1:1) shows the vibration of $\mathrm{Cr}-\mathrm{O}$ at wave number of $700 \mathrm{~cm}^{-1}$, and vibration $\mathrm{C}-\mathrm{H}, \mathrm{C}-\mathrm{O}$, and $\mathrm{O}-\mathrm{H}$ appear on the wave number of $2931,8-3448,7 \mathrm{~cm}^{-1}$. On comparison (1:2) $\mathrm{Cr}-\mathrm{O}$ at the wave number of $675 \mathrm{~cm}^{-1}$ and vibration $\mathrm{C}-\mathrm{H}$, $\mathrm{C}-\mathrm{O}$, and $\mathrm{O}-\mathrm{H}$ appears at the wave number of 2931,8-3441 $\mathrm{cm}^{-}$ 1. In comparison (1:3) $\mathrm{Cr}-\mathrm{O}$ at the wave numbers of $675 \mathrm{~cm}^{-1}$ and $\mathrm{C}-\mathrm{H}, \mathrm{C}-\mathrm{O}$, and $\mathrm{O}-\mathrm{H}$ vibrations appear on the wave number of $2931,8-3448,7 \mathrm{~cm}^{-1}$. FTIR spectrum in Figure 4 shows that all the comparisons the insertion process produces the FTIR spectrum which does not differ significantly so to determine the optimal insertion process requires others supporting characterization data.

Bentonite inserted compound the organometallic is further characterized using XRD analysis that shows that at a ratio of 
2.5: $1(\mathrm{~K})$ and 1: $1(\mathrm{~L})$ ratio is amorphous. Comparison of 1: 2 $(\mathrm{M})$ and a ratio of 1: $3(\mathrm{~N})$ produces diffraction that is not high tend to widen but still have crystallinity. The existence of diffraction that appears on region $2 \theta$ i.e. at $3-5^{\circ}$ diffraction angle, $3,3-5^{\circ}, 3,3-4,2^{\circ}, 3,3-13,6^{\circ}$ marks the typical peak on bentonite inserted by comparison (2.5:1), (1:1), (1:2), (1:3). Based on the data XRD measurement results are known to be diffraction most often appear at $4^{\circ}$ diffraction angle, $3.0^{\circ}, 5.0^{\circ}$, and $39^{\circ}$ in the presence of minerals montmorillonite, silicate minerals, and minerals Illite. According to Syuhada (2008), the value of cation s exchange more than 1.0 will reduced the increasing of $\mathrm{d}$-spacing. This matter due to the excess concentration of organometallic compounds will cause the Organometallic compound will be arranged within the Bentonite.

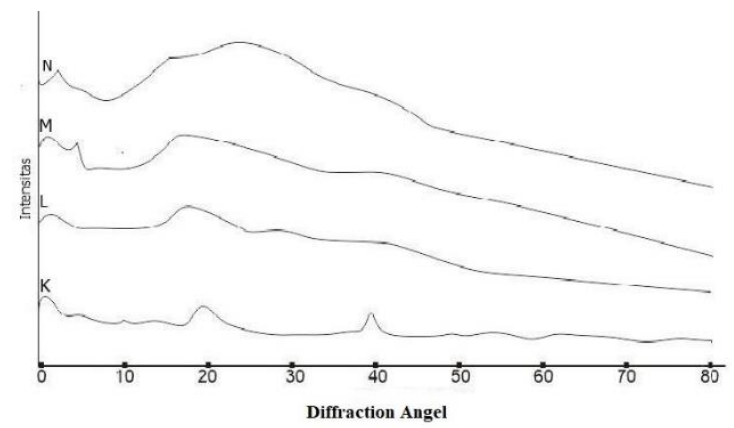

Figure 5. Identification of insertion bentonite with a ratio of 2.5: $1(\mathrm{~K}) ; 1: 1(\mathrm{~L}) ; 1: 2(\mathrm{M}) ; 1: 3(\mathrm{~N})$ using XRD analysis

Table 2. The composition of oxyde of the insted bentonite

\begin{tabular}{|c|c|c|c|c|c|}
\hline Sample & $\begin{array}{l}\mathrm{Al} 2 \mathrm{O} 3 \\
(\%)\end{array}$ & $\begin{array}{l}\mathrm{SiO} 2 \\
(\%)\end{array}$ & $\begin{array}{l}\text { P2O5 } \\
(\%)\end{array}$ & $\begin{array}{l}\mathrm{K} 2 \mathrm{O} \\
(\%)\end{array}$ & $\begin{array}{l}\mathrm{CaO} \\
(\%)\end{array}$ \\
\hline$(1: 2)$ & 2.7 & 6.7 & 0.34 & - & 0.33 \\
\hline$(1: 3)$ & 2 & 4.1 & 0.35 & - & 0.30 \\
\hline Sample & $\begin{array}{l}\mathrm{NiO} \\
(\%)\end{array}$ & $\begin{array}{l}\mathrm{CuO} \\
(\%)\end{array}$ & $\begin{array}{l}\mathrm{ZnO} \\
(\%)\end{array}$ & $\begin{array}{l}\mathrm{NiO} \\
(\%)\end{array}$ & $\begin{array}{l}\mathrm{CuO} \\
(\%)\end{array}$ \\
\hline$(1: 2)$ & 1.0 & 0.17 & - & -1.0 & 0.17 \\
\hline$(1: 3)$ & 1.0 & 0.17 & $-\overline{0}$ & -1.0 & 0.17 \\
\hline Sample & $\begin{array}{l}\mathrm{TiO} 2 \\
(\%)\end{array}$ & $\begin{array}{l}\text { V2O5 } \\
(\%)\end{array}$ & $\begin{array}{l}\mathrm{Cr} 2 \mathrm{O} 3 \\
(\%)\end{array}$ & $\begin{array}{l}\mathrm{MnO} \\
(\%)\end{array}$ & $\begin{array}{l}\mathrm{Fe} 2 \mathrm{O} 3 \\
(\%)\end{array}$ \\
\hline$(1: 2)$ & 0.42 & - & 76.28 & 1.1 & 9.64 \\
\hline$(1: 3)$ & $\begin{array}{l}0.27 \\
82.28 \\
1.2 \\
6.4\end{array}$ & $\begin{array}{l}-\quad- \\
82.28 \\
1.2 \\
6.4\end{array}$ & $\begin{array}{l}82.28 \\
82,28 \\
1.2 \\
6.4\end{array}$ & $\begin{array}{l}1.2 \\
82.28 \\
1.2 \\
6.4\end{array}$ & $\begin{array}{l}6.44 \\
82.28 \\
1.2 \\
6.4\end{array}$ \\
\hline $\begin{array}{l}\text { Samp } \\
\text { le }\end{array}$ & $\begin{array}{l}\text { SO3 } \\
(\%)\end{array}$ & $\begin{array}{l}\text { MoO3 } \\
(\%)\end{array}$ & $\begin{array}{l}\mathrm{EuO3} \\
(\%)\end{array}$ & \multicolumn{2}{|c|}{$\begin{array}{l}\mathrm{Bi} 2 \mathrm{O} 3 \\
(\%)\end{array}$} \\
\hline$(1: 2)$ & - & - & - & 1,2 & \\
\hline$(1: 3)$ & 0.95 & - & - & 1.3 & \\
\hline
\end{tabular}

Different diffraction positions will signifies the influence of the constituent atom different bentonite, and that affecting the intensity of X-ray diffraction. This analysis is in accordance with that analysis generated by infrared spectra states the existence of $\mathrm{O}-\mathrm{H}$ strain from the structure silicate. Thus the difference between the distance the field is caused by the number of atoms and the position of the atom in the cell. This also proposed by Tomuland Bald (2007)which states that the number of species insertion causes influence on distance interlayer and the strength of the crystal structure changed after physical activation. This crystal structure is related to the number electrons contained at a particular point and known as the intensity (I)(Ismunandar, 2006).

Based on FTIR data and analysis XRD, it is seen that the little shifting of diffraction angle on the comparison (2.5:1) and $(1: 1)$ so it cannot yet determine optimal ratio. Therefore selected comparison (1:2) and (1:3) are performed an optimum shift diffraction angle and subsequently characterized using XRF analysis. The data are presented in Table 2 showing the results $\mathrm{XRF}$ analysis on inserted bentonite Organometallic compound $\left[\mathrm{Cr}_{3} \mathrm{O}(\mathrm{OOCH})_{6}\left(\mathrm{H}_{2} \mathrm{O}\right)_{3}\left(\mathrm{NO}_{3}\right)\right]$ by ratio (1:2) and (1:3) with $\mathrm{Cr}_{2} \mathrm{O}_{3}$ metal oxide increase of $76.29 \%$ To $82.28 \%$ so on the comparison 1:3 insertion process of organometallic compound to In bentonite works perfectly because it has the highest percentage. Through XRF analysis data can be determined

The result of insertion of bentonite with the organometallic compound $\left[\mathrm{Cr}_{3} \mathrm{O}(\mathrm{OOCH})_{6}\left(\mathrm{H}_{2} \mathrm{O}\right)_{3}\left(\mathrm{NO}_{3}\right)\right]$ which is optimal in comparison (1:3) to be applied as the adsorbent of procion red.

\section{Effect of Adsorption Time of Colour Substance Procion Red Using activated and inserted Bentonite Organometallic Compounds $\left[\mathrm{Cr}_{3} \mathrm{O}(\mathrm{OOCH})_{6}\left(\mathrm{H}_{2} \mathrm{O}\right)_{3}\right.$ $\left.\left(\mathrm{NO}_{3}\right)\right]$}

The influence of time of adsorption of procion red is shown in Figure 6.

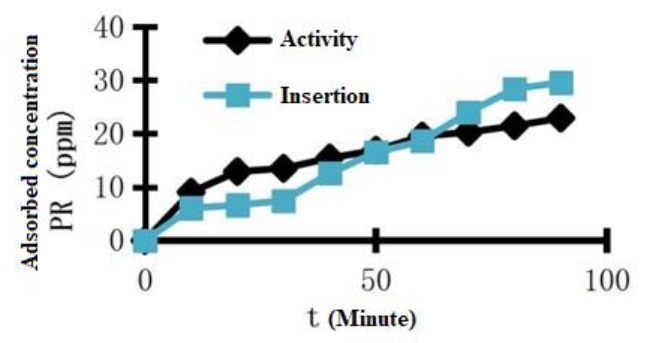

Figure 6. Effect of dye adsorption of procion red time using activated bentonite and inserted Bentonite

Figure 6 shows when the time of adsoprtion increases, it will also increase the procion red dye adsorbed. This is due to the longer the time of collision between adsorbents with adsorbate then the more adsorbate can adsorb by adsorbents. Inserted Bentonite has a quick adsorption time with the substance procion red adsorbed for $29.54 \mathrm{mg} / \mathrm{L}$ compared with activated bentonite at $22.90 \mathrm{mg} / \mathrm{L}$. This matter due to inserted bentonite has a distance between layers so it can quick adsorb the very procion red dye.

The data of influence time of adsorption is used to determine kinetic parameters i.e. the absorption rate. The adsorption rate data is calculated with the Langmuir-Hinshelwood equation. 
Data calculation of kinetic parameters presented in Figure 7 and 8.

Based on the Langmuir-Hinshelwood, the rate of adsorption constant can be calculated and presented in Table 4. The correlation coefficient obtained shows the existence of linear line equations. Equation of line with correlation coefficient (> $0.9)$ indicates that the adsorption kinetics the procion red satisfies the kinetics equation Langmuir-Hinshelwood.

Table 3 shows the rate of adsorption rate for activated bentonite greater than inserted bentonite. This is due to activated bentonite has a spacing between layers very small so when the adsorbate dye procion red entry more easily filled compared to the inserted bentonite has a greater spacing between layers because it has been inserted organometallic compound so that the activated bentonite is more reactive than on insertion bentonite.

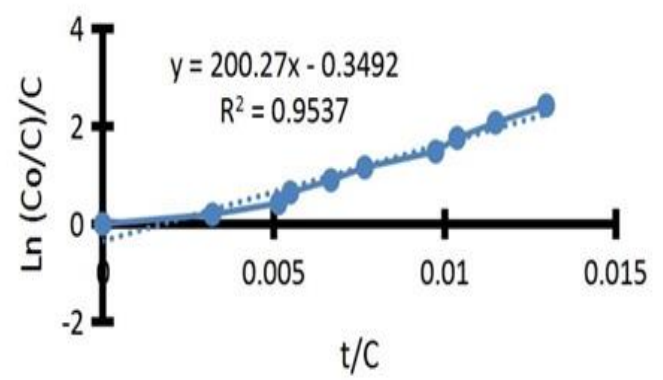

Figure 7. Kinetic parameters of adsorption of substances procion red by activated Bentonite

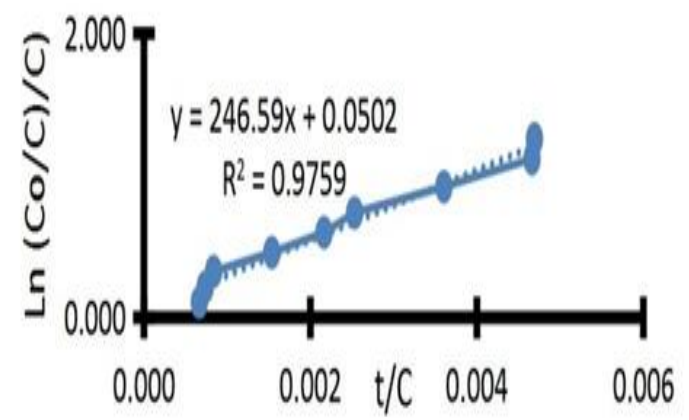

Figure 8. Kinetic parameters of adsorption of substances procion red by inserted Bentonite

\section{Effect of Temperature and Concentration of Procion} red, and Determination of Thermodynamic Parameters on The Activated and Inserted Bentonite

Effect of temperature on adsorption of procion red is presented in Figure 9 and 10. From the Figures 9 and 10, it can be sen that the higher temperature and concentration $(\mathrm{Mg} / \mathrm{L})$ will make the procion red adsorbed also increase. Figure 9 shows between Procion red. But Its also seen that the increasing of temperature did not causes the amount procion red absorbed procion too significantly. In Figure 10, the difference of point $(\mathrm{x}, \mathrm{y})$ is significant compared to Figure 9. Adjacent as in activated bentonite. The explanation of this phenomenom should be from the macro cations inserted in the deep layer of bentonite. The macro cations trapped the procion red inside of the adsorbent and the it is difficult to release it again.

The value of thermodynamic parameters of adsorption is listed in Table 4 and 5 . Table 4 shows that the maximum capacity of procion red dye adsorption (b) and energy of adsoprtion (E) on some concentrations by bentonite are activated and inserted bentonite shows irregular increases along increased temperature. The adsorption process occurs at varying temperatures is in the Endothermic conditions.

Table 5 shows the $\Delta \mathrm{H}$ value of adsorption of procion red by activated and inserted bentonite has decreased irregularly contrary with increasing concentration of varied procion red. The $\Delta S$ value of adsorption of procion red by activated and inserted bentonite shows the order of irregularity that occurs on the adsorption process. The adsorption process with the highest entropy is occured on activated bentonite with a concentration of $0.5 \mathrm{mg} / \mathrm{L}$ i.e. $278.99 \mathrm{~kJ} / \mathrm{mol}$, and in Inserted bentonite at $0.5 \mathrm{mg} / \mathrm{L}$ of concentration reached $315.08 \mathrm{~kJ} / \mathrm{mol}$.

Table 3. The adsorption rate values for activated bentonite and inserted bentonite

\begin{tabular}{lll}
\hline Adsorbent & $\begin{array}{l}\text { Rate of adsorption } \\
\left(\mathrm{min}^{-1}\right)\end{array}$ & $\mathrm{R}^{2}$ \\
\hline Activated & 0.0048 & 0.9537 \\
Inserted & 0.004 & 0.9759 \\
\hline
\end{tabular}

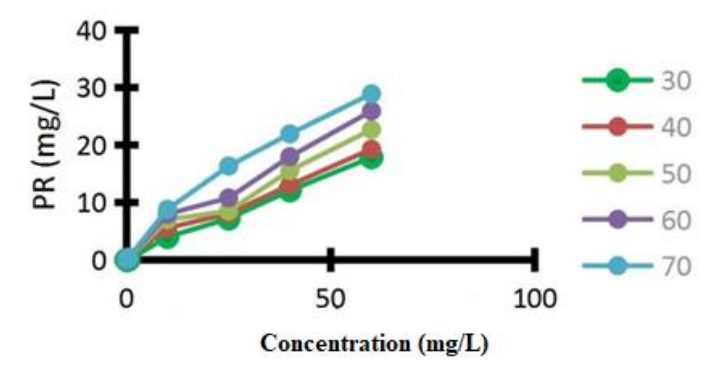

Figure 9. Effect of temperature and concentration on adsorption of procion red using activated bentonite

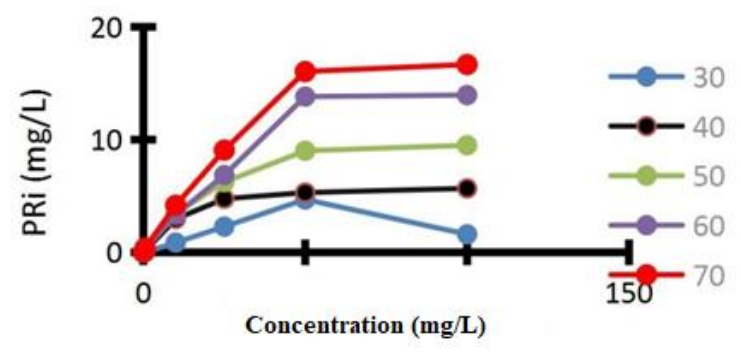

Figure 10. Effect of temperature and concentration on adsoprtion of procion red using inserted bentonite

\section{Effect of Initial pH 0n Adsorption of Dyestuffs Procion Red Using Activated and Inserted Bentonite}

Effect of $\mathrm{pH}$ on dye adsorption procion red by activated and inserted bentonite is presented in Figure 11. Procion red dye adsorption process by activated bentonite has an initial $\mathrm{pH}$ of 4 . After added hydrochloric acid $(\mathrm{HCl})$, the $\mathrm{pH}$ goes down to 3 and the number of procion red adsorpted increased. This phenomenon characterized by a colour change of procion red 
to become a pale red. On process addition of sodium hydroxide $(\mathrm{NaOH}), \mathrm{pH}$ incresed to $8,9,10$ and 11 , and it caused a decrease in the number of procion reds adsorbed. It is marked with a colour change to dark red.

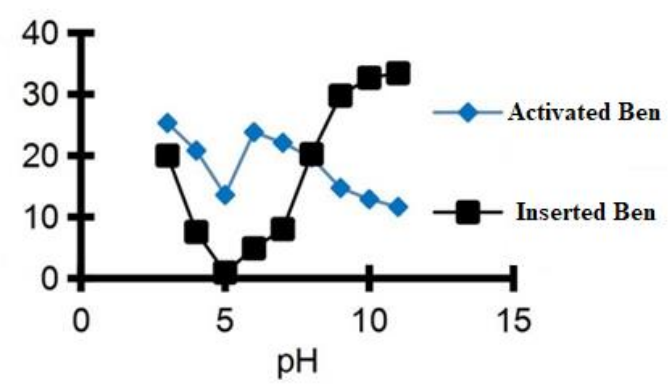

Figure 11. Effect of $\mathrm{pH}$ on procion red adsoprtion

Table 4. Thermodynamic parameters of Procion red adsorption by Activated and inserted bentonite

\begin{tabular}{llll}
\hline Adsorbent & $\begin{array}{l}\text { Temp. } \\
\left({ }^{\circ} \mathrm{C}\right)\end{array}$ & $\begin{array}{l}\mathrm{b} \\
(\mathrm{mg} / \mathrm{g})\end{array}$ & $\mathrm{E}(\mathrm{kJ} / \mathrm{mol})$ \\
\hline Activated & 30 & 55.86 & 3.1 \\
bentonite & 40 & 34.36 & 15.77 \\
& 50 & 39.32 & 12.15 \\
& 60 & 45.24 & 0.03 \\
& 70 & 72.99 & 7.24 \\
Inserted & 30 & -10.99 & -9.32 \\
bentonite & 40 & -7.74 & -32.37 \\
& 50 & -6.45 & -6.25 \\
& 60 & -4.75 & 17.05 \\
& 70 & -8.22 & 5.36 \\
\hline
\end{tabular}

Table 5 . The values of $\mathrm{R}, \Delta \mathrm{H}, \Delta \mathrm{S}$ with variations concentration of activated bentonite and bentonite inserted

\begin{tabular}{lllll}
\hline $\begin{array}{l}\text { Adsor } \\
\text { bent }\end{array}$ & Conc & $\mathrm{R}^{2}$ & $\Delta \mathrm{H}$ & $\Delta \mathrm{S}$ \\
\hline Activate & 0.5 & 0.9395 & 94413.78 & 278.99 \\
$\mathrm{~d}$ & 10 & 0.9987 & 51494.42 & 160.65 \\
bentonit & 25 & 0.7998 & 30274.59 & 84.88 \\
$\mathrm{e}$ & 40 & 0.9527 & 22244.1 & 59.86 \\
& 60 & 0.983 & 17651.45 & 44.91 \\
& & & & \\
Inserted & 0.5 & 0.8362 & 10572.82 & 315.08 \\
bentonit & 10 & 0.7825 & 44962.94 & 127.23 \\
$\mathrm{e}$ & 25 & 0.9284 & 34355.94 & 90.19 \\
& 50 & 0.9597 & 36281.46 & 94.106 \\
& 100 & 0.9166 & 52458.84 & 135.99 \\
\hline
\end{tabular}

In the adsorption process of procion red by inserted bentonite, it has an initial $\mathrm{pH}$ of 8.48 with the amount procion red adsorbed at $20.24 \mathrm{mg} / \mathrm{L}$. When it added with hydrochloric

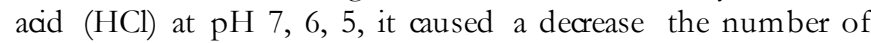
procion red absorbed. At $\mathrm{pH}$ 4. 3 amount of red absorbed procion return to increased indicated by pale red colour. Contrary to activated bentonite process, on inserted bentonite adsorbent shows the increasing in the amount of procion red absorbed at $\mathrm{pH}$ 9, 10 and 11, followed by the colour changes becomes dark red when it added with Sodium hydroxide $(\mathrm{NaOH})$. The existence of change of colour on the procion red adsorbed by both activated or inserted bentonite either on an acidic or base atmosphere is based on the effective $\mathrm{pH}$ of the procion red i.e. at $\mathrm{pH} 3-5$. When the atmosphere is acid then the colour will change to pale red, otherwise in an alkaline atmosphere the mixture will be a dark red.

\section{Interaction Study of Procion red Inserted Organo- metallic Compounds $\left[\mathrm{Cr}_{3} \mathrm{O}(\mathrm{OOCH})_{6}\left(\mathrm{H}_{2} \mathrm{O}\right)_{3}\left(\mathrm{NO}_{3}\right)\right]$ Using FT-IR Spectrophotometer}

The FT-IR spectrum of activated bentonite at before and after adsorbing procion red dye is presented in Figures 12 and 13.

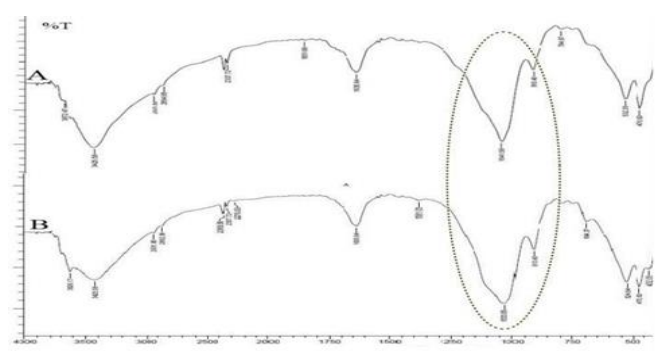

Figure 12. FT-IR spectrum of activated before (A) and bentonite inserts (B) after absorbing the procion red.

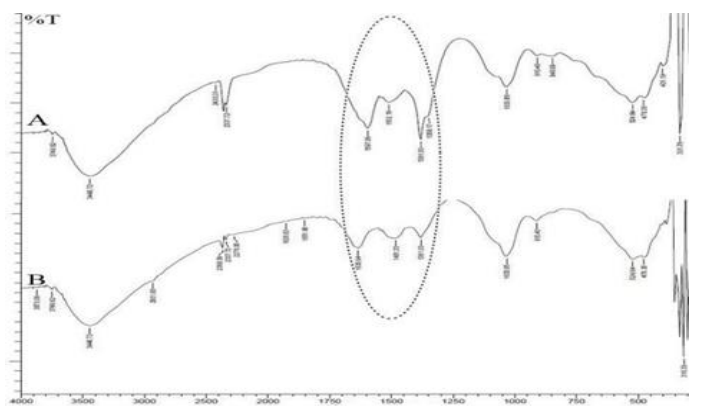

Figure 13. The FT-IR spectrum of bentonite inserted organometallic compounds before (A) and after (B) adsorb the procion dye red

Vibration of functional groups contained in procion red dye appears in a specific wave. Figure 12 shows changes in the FTIR spectrum. The wave number between activated bentonite before and after absorbing the dyestuff procion red that is not much different. On the wave number $470 \mathrm{~cm}^{-1}$, it represents vibration of $\mathrm{Si}-\mathrm{O}-\mathrm{Si}$ and $\mathrm{S}=\mathrm{O}$ of the dye procion red with sharp intensity. The bonding of activated bentonite after adsorption procion red appears on the wave number $1635.6 \mathrm{~cm}^{-1}$ indicates typical $\mathrm{N}=\mathrm{N}$ vibration in procion red. $\mathrm{N}-\mathrm{H}$ vibrations are dogged on the duster functional procion red appears on number $3615 \mathrm{~cm}^{-1}$.

Figure 13 shows the change of the inserted bentonite spectrum after adsorb the procion red dye. It is seen the vibration bonds of dusters functional procion red appears at $1635 \mathrm{~cm}^{-1}$ that shows the ribbon absorption for $\mathrm{N}=\mathrm{N}$ indicating the presence azo group (Widjajanti et al, 2011). 


\section{CONCLUSION}

Bentonite inserted with an organometallic compound $\left[\mathrm{Cr}_{3} \mathrm{O}(\mathrm{OOCH})_{6}\left(\mathrm{H}_{2} \mathrm{O}\right)_{3}\left(\mathrm{NO}_{3}\right)\right]$ which is characterized by FT-IR spectrophotometer indicates an insertion process but it has not yet show optimal result so characterization is also done using XRD. The XRD result shows optimal insertion process in comparison (1:2) and (1:3) with angular shifts diffraction of 5.00 , and $39^{\circ}$ of initial activated bentonite at $20.8^{\circ}$. On inserted bentonite, it is seen diffraction not high and tends to widened but still has crystallinity. To support of process success insertion carried out advanced characterization using XRF analysis. It shows optimized inserted bentonite process on comparison (1: 3) with the percentage of oxide metals of $82.28 \%$.

Adsorption of procion red dye using bentonite inserted compound Organometallic [ $\mathrm{Cr} 3 \mathrm{O}(\mathrm{OOCH}) 6(\mathrm{H} 2 \mathrm{O}) 3(\mathrm{NO} 3)]$ studied using kinetic parameters, thermodynamics, and $\mathrm{pH}$. Adsorption of dyestuff procion red with activated bentonite has an absorption rate of $0.0048 \mathrm{~min}^{-1}$ while on inserted bentonite has the rate of $0.004 \mathrm{~min}^{-1}$. Parameter thermodynamic adsorption by both adsorbents with temperature variations shows the increasing and the decreasing, and as well with the value of adsorption energy (E). The highest value of energy adsorption at a temperature of $60^{\circ} \mathrm{C}$ for $72.99 \mathrm{~kJ} / \mathrm{mol}$ and at the inserted bentonite is $17.05 \mathrm{~kJ} / \mathrm{mol}$ at a temperature of $60^{\circ} \mathrm{C}$. On $\mathrm{pH} 5$ there is an increasing in the number of procion red adsorbed by activated bentonite i.e. $25.32 \mathrm{mg} / \mathrm{L}$ and on inserted bentonite amount of red absorbed procion of $33.38 \mathrm{mg} / \mathrm{L}$ at $\mathrm{pH} 11$.

\section{ACKNOWLEDGEMENT}

We thanks Sriwijaya University for support this research through "Hibah PNBP 2016" to A.L.

\section{REFERENCES}

Altunlu, M. and Yapar, S. 2007. Effect of $\mathrm{OH}^{-} / \mathrm{Al}^{+3}$ and $\mathrm{Al}^{+3} /$ day ratios on the adsorption properties of $\mathrm{Al}$-pillared bentonites. Colloids and Surfaces A: Physicochemical and Engineering Aspects, 306(1) : 88-94.

Caglar, B., Cubuk, O., Demir, E., Coldur, F., Catir, M., Topau, C., and Tabak, A. 2015. Characterization of AlFe-pillared Unye bentonite: A study of the surface acidity and catalytic property. Journal of Molecular Structure, 1089 : 59-65.

Chaiko, D. 2003. Process for the Preparation of Organodays., Patent : US 6521678 B1, USA

Dewi, M., dan Hidayati, N. 2012. Penigkatan Mutu Minyak Goreng Curah Menggunakan Adsorben Bentonit Teraktivasi. Journal of Chemistry, 1(2) : 47-54.

Handayani, Sri., Kusumawardani, Cahyono., dan Budiasih, Sri. 2013. Sintesis Senyawa Sinamalaseton melalui Reaksi Hidrotalsit Mg-Al untuk Aplikasi Tabir Surya. Yogyakarta: UNY

Koetiari, T. 2014. Karakterisasi Bentonit Terpilar Logam Aluminium pada Variasi Suhu Kalsinasi. Molekul.9(2) :144154.

Kouraichi, S., El-Hadi Samar, M., Abbessi, M., Boudouh, H., Balaska, A.,2015. Pillared days as catalysts for methyl parathion removal by advanced oxidation processes. Catalysis Science and Technology, 5(2) : 1052-1064.
Lesbani, A. 2008. Sintesis dan Struktur Kristal Ion. $\left[\mathrm{Cr}_{3} \mathrm{O}\left(\mathrm{OOCC}_{6} \mathrm{H}_{5}\right)_{6}\left(\mathrm{H}_{2} \mathrm{O}\right)_{3}\right]_{4}\left[\alpha-\quad \mathrm{SiW}_{12} \mathrm{O}_{40}\right] 10 \mathrm{H}_{2} \mathrm{O}$. $8 \mathrm{CH}_{3} \mathrm{COCH}_{3}$. Jurnal Matematika dan Sains, 13(2) : 60-65.

Mahmoud, M.E., Nabil, G., El-Mallah, N., El- Mallah, N., Bassiouny, H., Kumar, S., Abdel-Fattah, T. 2016. Kinetics, isotherm, and thermodynamic studies of the adsorption of reactive red 195 A dye from water by modified Switchgras s Biochar adsorbent. Journal of Industrial and Engineering Chemistry. 34 : 321-330.

Mikrajuddin, A., Khairurrijal., Khairurrijal,.

Ahmad R.M., Liherlinah dan Muhammad Sanny. 2008. Sintesis dan Pengujian Katalis.Nanokristallin $\mathrm{Cu} / \mathrm{ZnO} / \mathrm{Al}_{2} \mathrm{O}_{3}$ dengan Metode Pemanasan dalam Larutan Polimer untuk Aplikasi Konversi Metanol Menjadi Hidrogen. Jurnal Nano Sains dan Nanoteknologi, 1(28) : 5-7.

Noyan, H., Onal, M., and Sarikaya,Y. 2007.

The Effect of Sulfuric Adid on a Cristalinity, Surface Area, Porocity, Surface Acidty and Bleaching Power of Bentonit, Journal Food Chemistry. 105 : 156-163.

Nurwijayadi. 1998. Pengukuran Luas Permukaan Nanokatalis. Pusat Pendidikan dan Latihan Badan Tenaga Atom Nasional, Yogyakarta.

Ohto, A., Yamamoto, A. T., Abe, M., Ito, T., Sasaki, Y., Umakoshi, K., and Cannon, R. D., 1995, Structure and Vibrational Spectra of Trinudear Metal Cluster Complexes. A Question of Symmetry, Chemistry Letters, 97-98

Utami, H., \& Siburian, D. (2017). Organometallic [Fe3O(OOCC6H5)6(H2O)3](NO3) as Intercalant of Bentonite. Science \& Technology Indonesia, 1(1), 20-24.

Simamora, J., Martin, Y., Gusnedi, H.2016. Pengaruh Penambahan Asam Sulfat (H2SO4) pada Bentonit untuk Penurunan Nilai Tahanan Pentanahan. Jurnal Rekayasa dan Teknologi Elektro. 10(1) : 30-37.

Sukandarrumi. 1999. Bahan Galian Industri. Yogjakarta: Gajah Mada University Press

Syuhada, Raehmad Wijaya, Jayatin, Saeful Rohman. 2009. Modifikasi Bentonit (Clay) menjadi Organoday dengan Penambahan Surfaktan, Jurnal Nanosains \& Nanoteknologi, 2(1) : 48-51.

Tien, C. \& Ramarao, B. V. 2014. Further examination of the relationship between the Langmuir kinetics and the Lagergren and the second-order rate models of batch adsorption. Separation and Purification Technology, 136 : 303308.

Uchida, S., Lesbani, A., Ogasawara, Y., Mizuno, N. 2012. Ionic Crystals $\left[\mathrm{M}_{3} \mathrm{O}\left(\mathrm{OOCC}_{6} \mathrm{H}_{5}\right)_{6}\left(\mathrm{H}_{2} \mathrm{O}\right)_{3}\right]_{4}\left[\alpha-\mathrm{SiW}_{12} \mathrm{O}_{40}\right](\mathrm{M}=$ $\mathrm{Cr}$, Fe) as Heterogeneous Catalysts for Pinacol Rearrangement. Inorganic Chemistry, 51(2) : 775-777.

Utami, H., \& Siburian, D. (2017). Organometallic [Fe3O(OOCC6H5)6(H2O)3](NO3) as Intercalant of Bentonite. Science \& Technology Indonesia, 1(1).

Wang, T., Runliang, Z,. Ge F, Chen W. 2009.Intercalation of Both CTMAB and $\mathrm{Al}_{13}$ into Monmorillonite. Journal of Colloid and Interface Science. 335(1): :77-83.

Widjajanti, E., dkk. 2011. Pola Adsorpsi Zeolit Terhadap Pewarna Azo Metil Merah dan Metil Jingga. Prosiding Seminar Nasional Penelitian. Pendidikan dan Penerapan Mipa. Jurusan Pendidikan Kimia. Yogyakarta :FMIPA UNY. 